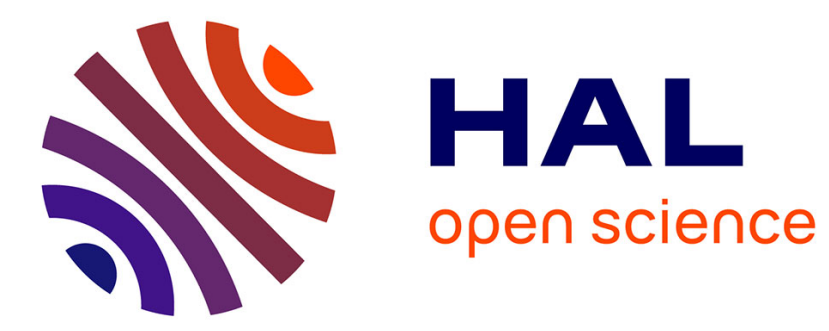

\title{
Synthesis and Crystal Structure of LiZn13
}

Dieter Fischer, Martin Jansen

\section{To cite this version:}

Dieter Fischer, Martin Jansen. Synthesis and Crystal Structure of LiZn13. Journal of Inorganic and General Chemistry / Zeitschrift für anorganische und allgemeine Chemie, 2010, 636 (11), pp.2102. 10.1002/zaac.201009108 . hal-00599876

\section{HAL Id: hal-00599876 https://hal.science/hal-00599876}

Submitted on 11 Jun 2011

HAL is a multi-disciplinary open access archive for the deposit and dissemination of scientific research documents, whether they are published or not. The documents may come from teaching and research institutions in France or abroad, or from public or private research centers.
L'archive ouverte pluridisciplinaire HAL, est destinée au dépôt et à la diffusion de documents scientifiques de niveau recherche, publiés ou non, émanant des établissements d'enseignement et de recherche français ou étrangers, des laboratoires publics ou privés. 


\section{Synthesis and Crystal Structure of LiZn $\mathbf{n}_{13}$}

\begin{tabular}{|c|c|}
\hline Journal: & Zeitschrift für Anorganische und Allgemeine Chemie \\
\hline Manuscript ID: & zaac. 201000222 \\
\hline Wiley - Manuscript type: & Article \\
\hline $\begin{array}{r}\text { Date Submitted by the } \\
\text { Author: }\end{array}$ & 28-May-2010 \\
\hline Complete List of Authors: & $\begin{array}{l}\text { Fischer, Dieter; MPI fuer Festkoerperforschung, Chemie III } \\
\text { Jansen, Martin; MPI für Festkörperforschung }\end{array}$ \\
\hline Keywords: & $\begin{array}{l}\text { Lithium, Zinc, Structure elucidation, Thermal properties, } \\
\text { Intermetallic phases }\end{array}$ \\
\hline
\end{tabular}

\section{(5) ScholarONE \\ Manuscript Central}


DOI: 10.1002/zaac.200((will be filled in by the editorial staff))

\section{Synthesis and Crystal Structure of $\operatorname{LiZn}_{13}$}

* Prof. Dr. M. Jansen

Fax: $+49(0) 711-6891502$

E-mail M.Jansen@fkf.mpg.de

[a] Max-Planck-Institut für Festkörperforschung

Postfach 800665

D-70506 Stuttgart

\section{Introduction}

The cubic $\mathrm{NaZn}_{13}$ type of structure [1-4], which is genuinely adopted by binary alloys of alkali metals and zinc, or cadmium, of respective composition, is featuring several remarkable characteristics. Among others, the space filling tiling of three kinds of polyhedra, icosahedra, snub cube and tetrahedral star, do not show significant variations in the dimensions with the size of the alkali metal incorporated in the center of the snub cube [4]. This is e.g. reflected by the rather low increase of the lattice constant from 1379, to 1384, and to $1392 \mathrm{pm}$ in the row $\mathrm{KCd}_{13}, \mathrm{RbCd}_{13}, \mathrm{CsCd}_{13}$, respectively. From this fact one might deduce that the size of the alkali metal would not crucially determine the stability range of the structure type. Against this background, the nonexistence of a representative of this structure type involving lithium has attracted our attention.

Since the binary system $\mathrm{Li} / \mathrm{Zn}$ appears to have been extensively studied experimentally $[5,6]$ using the common metallurgical tools, we assume that $\mathrm{LiZn}_{13}$ does not exist as a thermodynamically stable compound. Recently, we have demonstrated that our low-temperature atomic beam deposition technique (LT-ABD) $[7,8]$ is well suited to also synthesize metastable intermetallics. Along such a procedure we have realized the metastable cubic Lavesphase $\beta-\mathrm{CaLi}_{2}$ for the first time, which transforms at $150{ }^{\circ} \mathrm{C}$ to the known thermodynamic stable structure of $\alpha-\mathrm{CaLi}_{2}$ ( $\mathrm{MgZn}_{2}$-type) [9]. We have employed our preparation technique at investigating the system $\mathrm{Li} / \mathrm{Zn}$ and have identified new $\mathrm{LiZn}_{13}$.

Thus far, several phases have been reported to exist in the system $\mathrm{Li} / \mathrm{Zn}$, however, only $\mathrm{LiZn}$ (NaTl structure-type) is well documented and unambiguously confirmed [10]. For the intermetallics $\operatorname{LiZn}_{2.5}$ and $\mathrm{LiZn}_{9}$ ( $\beta$ '-phase), only the lattice parameters were given $[6,11]$. The $\beta$ '-phase was claimed to show a homogeneity range of up to $\mathrm{LiZn}_{4}$ [12], 
and to adopt a hexagonal structure (hcp) with a random distribution of zinc and lithium [13]. $\mathrm{LiZn}_{1.5}$ and $\mathrm{LiZn}_{2}$ were observed in the course of constitutional analysis of the $\mathrm{Li} / \mathrm{Zn}$ system, however, were not characterized in any respect $[6$, 12].

\section{Results and Discussion}

Co-depositing zinc and lithium with a ratio of $\mathrm{Zn}: \mathrm{Li}=13: 1$ onto single-crystalline sapphire substrates at $-196{ }^{\circ} \mathrm{C}$ results in grey-metallic samples, which show up to $-50{ }^{\circ} \mathrm{C}$ diffraction patterns of a hexagonal-closed-packed phase with lattice constants of $\mathrm{a}=277.04(6), \mathrm{c}=439.07(9) \mathrm{pm}$. These values are in good agreement with the lattice constants of the $\beta$ '-phase $\mathrm{Li}_{0.1} \mathrm{Zn}_{0.9}$ reported previously with $\mathrm{a}=278.2, \mathrm{c}=438.5 \mathrm{pm}[6]$. The structure refinement by the Rietveld method confirms for the here obtained alloy $\mathrm{Li}_{0.07} \mathrm{Zn}_{0.93}$ the same structure, with a random atomic distribution of zinc and lithium at the sites of a hep arrangement (for details see [14]).

By subsequent warming up to room temperature, the samples transform completely into the new phase $\mathrm{LiZn}_{13}$ (Figure 1). The diffraction patterns of $\mathrm{LiZn}_{13}$ can be indexed assuming a cubic unit cell, with a refined latticed constant of $\mathrm{a}=1234.92(6) \mathrm{pm}$. The structure determined by the Rietveld method reveals $\mathrm{LiZn}_{13}$ to be isostructural to $\mathrm{NaZn}_{13}$ [4] (Figure 2). The refinements indicate a mixed occupation of zinc and lithium on the sites $8 \mathrm{a}$ : $\mathrm{Li}(1 / 4,1 / 4,1 / 4)$ and $8 \mathrm{~b}$ : $\mathrm{Zn}$ $(0,0,0)$ with an average of the $\mathrm{Li} / \mathrm{Zn}$ substitution, respectively on both $8 \mathrm{a}$ and $8 \mathrm{~b}$ sites, of about $25 \%$. Table 1 shows the crystal data of the structure refinement of a texture-free X-ray pattern including interatomic distances. The crystal structure consists of a 3-dimensional zinc network built up by corner-connected, slightly distorted stella quadrangulae ( $\mathrm{Zn} 2$ on $96 \mathrm{i}$ site). This network generates $\mathrm{Zn}$-icosahedra, which are centered by zinc ( $\mathrm{Zn} 1$ : 8b). Lithium is located in the centers of snub cubes formed by $24 \mathrm{Zn} 2$ atoms.

The rigid zinc network of the $\mathrm{NaZn}_{13}$ structure type exhibits only slight response at varying the type of alkali metals incorporated. This is reflected by the small difference of $1.5 \%$ between the lattice constants of $\mathrm{NaZn}_{13}(\mathrm{a}=1227.3)$ and $\operatorname{RbZn}_{13}(\mathrm{a}=1245.2)$ [4]. Therefore, we expected for $\mathrm{LiZn}_{13}$ a slightly smaller lattice constant compared to $\mathrm{NaZn}_{13}$. Surprisingly the lattice constant of $\mathrm{LiZn}_{13}$ has been reproducibly found to be larger, ranging between the values of $\mathrm{NaZn}_{13}$ and $\mathrm{KZn}_{13}$. We regard the mixed occupation of the center of the $\mathrm{Zn}$-icosahedra with $25 \%$ of lithium the main reason for this observation. Such an explanation appears to be reasonable since the larger atom/ion radius of Li should effect an expansion of the zinc network, and thus a respective increase of the lattice constant.

$\mathrm{LiZn}_{13}$ decomposes irreversibly to hexagonal, metallic zinc by further heating up to $160{ }^{\circ} \mathrm{C}$ (Figure 1). The refinement of the lattice constants has resulted in $\mathrm{a}=266.04(2)$ und $\mathrm{c}=$ 496.06(5) pm (room temperature), which is in good agreement with literature data reported for elemental zinc a $=266.5$ und $\mathrm{c}=494.7 \mathrm{pm} \mathrm{[15].} \mathrm{We} \mathrm{were} \mathrm{unable} \mathrm{to} \mathrm{trace} \mathrm{the}$ release of lithium by X-ray powder diffraction, obviously because of the small amounts or the fine dispersion of Li. Samples, which were deposited in the temperature range between $-50{ }^{\circ} \mathrm{C}$ and room temperature onto a sapphire substrate, contain mixtures of the $\beta$ '-phase, $\operatorname{LiZn}_{13}$ and metallic zinc in different ratios, depending on the preparation conditions. Occasionally mixtures of these 
phases were also found in samples deposited at $-196{ }^{\circ} \mathrm{C}$. Furthermore a slow transformation of $\mathrm{LiZn}_{13}$ into zinc occurs already at room temperature, during several days.

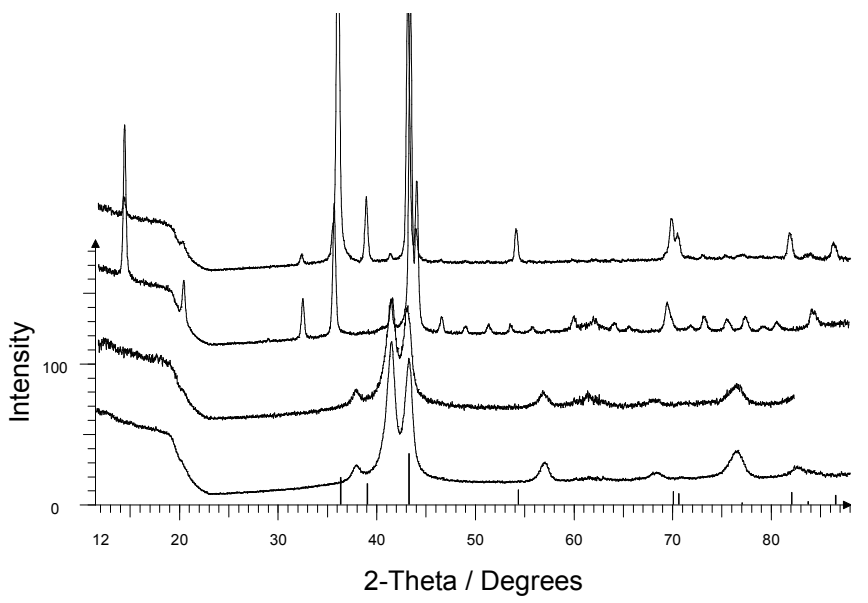

Figure 1. X-ray powder patterns of a $\mathrm{Zn} / \mathrm{Li}$ co-deposition at $196^{\circ} \mathrm{C}$ onto a sapphire substrate (ratio $\mathrm{Zn}: \mathrm{Li}=13: 1$ ); scans measured at -196 ( $\beta$ '-phase), -50 ( $\beta$ '-phase), $25\left(\operatorname{LiZn}_{13}\right), 160{ }^{\circ} \mathrm{C}$ (Zn) from bottom to top; tick marks: metallic Zn (background s. experimental).

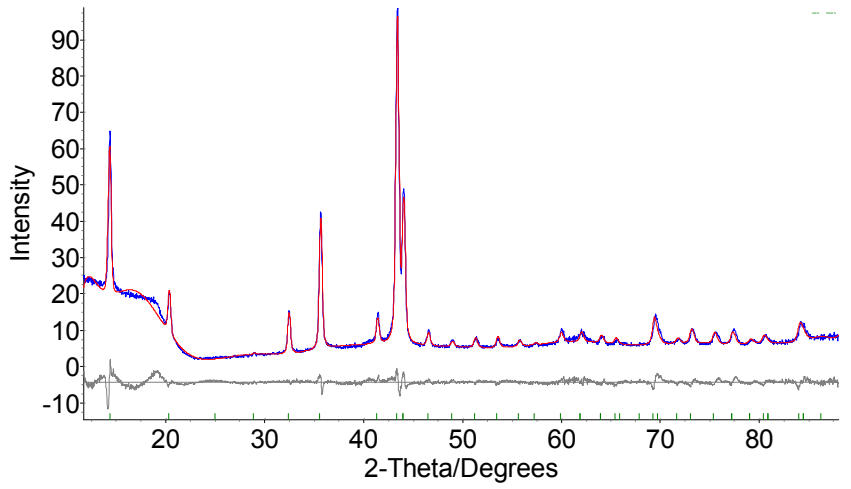

Figure 2. Rietveld refinement plot of $\operatorname{LiZn}_{13}$ : observed pattern (blue), fitted profile (red), difference profile (grey), tick marks: $\mathrm{LiZn}_{13}$.

Table 1. Crystal data and structure refinement of $\operatorname{LiZn}_{13}[19]$.

\begin{tabular}{ll}
\hline Formula & $\mathrm{LiZn}_{13}$ \\
Weight $(\mathrm{g} / \mathrm{mol})$ & 857.0
\end{tabular}

Crystal system

Space group

Lattice constant (pm)

Formula units

Cell volume $\left(10^{6} \cdot \mathrm{pm}^{3}\right)$

Mole volume $\left(\mathrm{cm}^{3} / \mathrm{mol}\right)$

X-ray density $\left(\mathrm{g} / \mathrm{cm}^{3}\right)$

Radiation

Measured range (20)

Reflexes

Parameter

Crystal size (nm)

Atomic positions

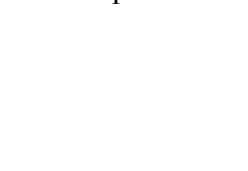

Isotropic thermal displacement $B_{e q}$

$\mathrm{R}_{\mathrm{p}}, \mathrm{R}_{\mathrm{wp}}, \mathrm{R}_{\text {Bragg }}$

Selected interatomic distances (pm)

\section{Conclusions}

The co-deposit of lithium and zinc at low temperature onto a sapphire substrate consists of the $\beta$ '-phase with random $\mathrm{Zn} / \mathrm{Li}$ distribution, which transforms while warming up to room temperature into $\mathrm{LiZn}_{13}$. The occupation of the $\mathrm{Zn}$ icosahedra in $\mathrm{LiZn}_{13}$ with ca. $25 \%$ lithium results in an expansion of the zinc network and seems to be relevant for the stability of the intermetallic $\mathrm{LiZn}_{13}$.

The results presented illustrate that as a particular advantage the synthesis method of LT-ABD is well suited for the synthesis of metastable solids $[16,17]$. As a crucial feature of this approach the reactants are dispersed on an atomic scale. Thus, the transport distances during the subsequent solid state reactions are reduced to atomic scales allowing 
them to be run at extremely low thermal activation. Combining the deposition technique with a specially adapted procedure of X-ray powder diffraction analysis offers high potential of exploring the stability ranges of phases, including metastable ones, in a given system.

\section{Experimental Section}

\section{Synthesis}

Zinc (>99.9\%, Fluka) and Lithium (distilled, >99.9 \%, Merk) were separately evaporated from a pyrolytic $\mathrm{BN}$-crucible with standard effusion cells (Dr. Eberl MBE-Komponenten $\mathrm{GmbH}$ ), which was held at a constant temperature of $220(\mathrm{Zn})$ and $300{ }^{\circ} \mathrm{C}(\mathrm{Li})$ in an ultra high vacuum chamber. Both metals were deposited simultaneously onto sapphire substrates $((0001)$ orientation, epitaxial polished, CrysTec $\mathrm{GmbH}$ ) for a period of 5 to 7 hours. Ultra high vacuum of 2 to $7 \times 10^{-9}$ mbar was maintained during preparation in the deposition chamber by using a turbo molecular and cryo-pump system including a liquid nitrogen filled cold trap; for further details of the preparation method see $[7,8]$. The residual gas was monitored by quadrupole mass spectrometers (QME 220, Pfeiffer Vacuum GmbH; C-100M, Leybold-Inficon), and the substrate temperature was controlled using a temperature sensor PT-100 placed in the sample holder. The composition of the obtained metallic-grey samples with a thickness of ca. $100 \mathrm{~nm}$ was determined by ICP-OES to 93 at $\% \mathrm{Zn}$ and 7 at $\% \mathrm{Li}$. The substrates with the deposited samples were transferred from the deposition chamber to an X-ray diffractometer, while maintaining vacuum and cooling, by means of a car transfer system.

\section{Structure Determination}

The powder diffraction patterns were recorded with a $\theta / \theta$ X-ray powder diffractometer (D8-Advance, Bruker AXS) with parallel beam geometry (Goebel mirror, $\mathrm{Cu}-\mathrm{K} \alpha$ ) in an X-ray chamber under high vacuum (ca. $1 \times 10-7$ mbar) in reflection mode. Each X-ray pattern was measured at an angle of incidence of $10^{\circ}$ using an area sensitive detector (GADDS, Bruker AXS). The corresponding pattern was obtained by integration of the two dimensional diffraction cones. The background from $20^{\circ}$ on in $2 \theta$ was reduced by a slit inside the vacuum chamber. For indexing and structure refinements (Rietveld method), the software Topas (Bruker AXS) was employed 18].

\section{References}

[1] J. A. A. Ketelaar, J. Chem. Phys. 1937, 5, 668.

[2] E. Zintl, W. Haucke, Z. Elektrochem. 1938, 44, 104.

[3] D. P. Shoemaker, R. E. Marsh, F. J. Ewing, L. Pauling, Acta. Cryst. 1952, 5, 637.

[4] M. Wendorff, C. Röhr, J. Alloys Compd. 2006, 421, 24.

[5] A. D. Pelton, J. Phase Equilibria 1991, 12, 42.

[6] E. Zintl, A. Schneider, Z. Elektrochem. Angew. Phys. Chem. 1935, 41, 764.

[7] D. Fischer, M. Jansen, J. Am. Chem. Soc. 2002, 124, 3488.

[8] M. Jansen, Angew. Chem. 2002, 114, 3896; Angew.

Chem. Int. Ed. 2002, 41, 3746.

[9] D. Fischer, M. Jansen, Z. Anorg. Allg. Chem. 2003, 629, 1934.

[10] K. Kuriyama, S. Saito, K. Iwamura, J. Phys. Chem. Solids 1979, 40, 457.

[11] H. Schönemann, H. U. Schuster, Rev. Chim. Min. 1976, 13,32 .

[12] G. Grube, H. Voßkühler, Z. Anorg. Allg. Chem. 1933, $215,211$.

[13] M.-P. Bichat, J.-L. Pascal, F. Gillot, F. Favier, Chem. Mater. 2005, 17, 6761 .

$\mathrm{Li}_{0.07} \mathrm{Zn}_{0.93}: \mathrm{a}=277.04(6), \mathrm{c}=439.07(9) \mathrm{pm}, \mathrm{P6}_{3} / \mathrm{mmc}$, $\mathrm{Zn} / \mathrm{Li}:(1 / 3,2 / 3,1 / 4), \mathrm{B}_{\mathrm{eq}}=0.4, \mathrm{R}_{\mathrm{p}}=4.6 \%, \mathrm{R}_{\mathrm{wp}}=5.9 \%$, $\mathrm{R}_{\mathrm{Bragg}}=1.3 \%$, The $\mathrm{Zn} / \mathrm{Li}$ ratio could not be refined because of high textured diffraction patterns. $1965,26,63$. 
1

2

3

4

5

6

7

8

9

10

11

12

13

14

15

16

17

18

19

20

21

22

23

24

25

26

27

28

29

30

31

32

33

34

35

36

37

38

39

40

41

42

43

44

45

46

47

48

49

50

51

52

53

54

55

56

57

58

59

[16] D. Fischer, M. Jansen, Angew. Chem. 2002, 114, 1831;

Angew. Chem. Int. Ed. 2002, 41, 1755.

[17] Y. Liebold-Ribeiro, D. Fischer, M. Jansen, Angew.Chem. 2008, 120, 4500; Angew. Chem. Int. Ed. 2008, 47, 4428.

[18] A. A. Coelho, Topas, General Profile and Structure Analysis Software for Powder Diffraction Data, Vers.

4.0, Bruker AXS GmbH, Karlsruhe, Germany 2008.

[19] Further details on the crystal structure investigations can

be obtained from the Fachinformationszentrum Karlsruhe,

76344 Eggenstein-Leopoldshafen, Germany (Fax:

+49-7247-808-666; E-Mail: crysdata@fiz-karlsruhe.de)

on quoting the depository number CSD-421842.

Received: ((will be filled in by the editorial staff)) Published online: ((will be filled in by the editorial staff) 
